\title{
Increasing Diversity in Engineering: Capacity Building Matters
}

Joanita M. Kant ${ }^{1}$, Suzette R. Burckhard ${ }^{2}$, Whitney K. Kilts ${ }^{3}$, and Kyungnan Min $^{2}$

${ }^{1}$ Research Scientist, ${ }^{2}$ Faculty, ${ }^{3}$ Graduate Student

Department of Civil and Environment Engineering, South Dakota State University, Brookings,

SD, USA (e-mails: Joanita.Kant@sdstate.edu, and Suzette.Burckhard@sdstate.edu)

\begin{abstract}
In an effort to prepare more Native American engineers, counting the numbers who complete the educational task is important. More often overlooked, however, is that capacity building is another key measure of success, since reaching critical mass to obtain the numbers may take considerable time. In this paper, the co-authors are both the researchers and the research subjects. We are four engineers and/or scientists with advanced degrees with key roles in a multiyear collaborative pre-engineering education initiative between a tribally controlled college and two mainline universities. From our perspectives at one of those two mainline universities, we each wrote an essay reflecting on pre-determined questions. We briefly present our qualifications and then assess capacity building related to the summer camp experiential learning aspect of the initiative. We qualitatively analyze the essays and present persistent themes, along with consensus and divergent opinions. Four common themes dominated the essays including the importance of: (1) using experiential learning pedagogy, (2) building lasting relationships and networking, (3) including cross-disciplinary connectivity, and (4) taking advantage of positive but unintended consequences. We provide a recommended bibliography for faculty, staff, graduate students, and undergraduate student interns to provide a shared base of knowledge to improve collaborative cohesion.
\end{abstract}

Key words: Assessment, Native American engineers, experiential learning

\section{Introduction}

This study is important because Native Americans are severely under-represented in STEM fields $^{1-3}$. A goal of the National Science Foundation (NSF), through STEM education initiatives, is to encourage inclusion of under-represented ethnic groups and minorities to better reflect the make-up of the American population as a matter of social justice and as a source of diverse perspectives that can benefit all ${ }^{4}$. Capacity building for Tribally Controlled Colleges (TCCs) is a major component of measuring success, even though the numbers of students who earn degrees and establish careers remain important to all stake holders ${ }^{5}$.

The focus of this paper is to report on progress in capacity building through NSF-funded summer camps, designed primarily for Native American students at a TCC on Pine Ridge Reservation (PRR) in South Dakota (and extending slightly into Nebraska). The summer camps are essential activities within NSF funded OSSPEEC, an acronym for Oglala Lakota College (OLC), South Dakota State University (SDSU), South Dakota School of Mines and Technology (SDSMT) PreEngineering Education Collaborative (PEEC) (Fig. 1). 


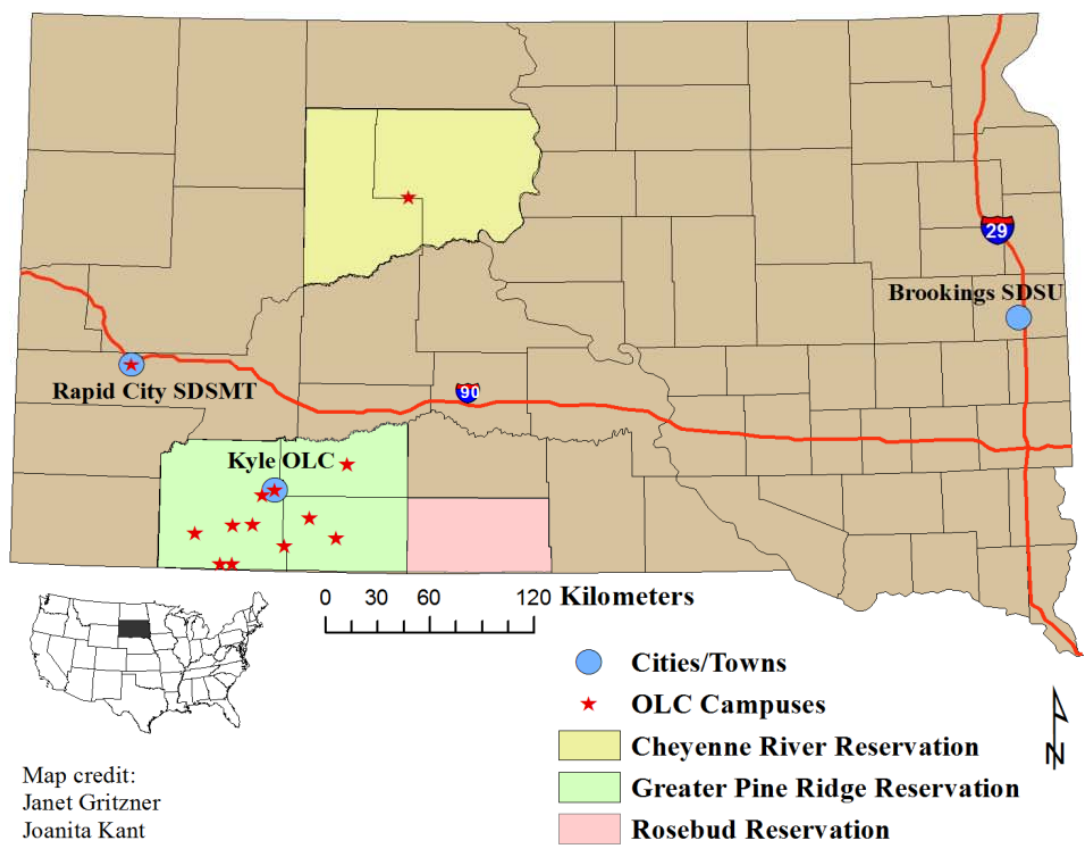

Figure 1. OLC's main administrative campus is near Kyle, South Dakota, on Pine Ridge Reservation, but they maintain thirteen campuses in South Dakota. SDSU and SDSMT are in Brookings and Rapid City, South Dakota, respectively.

An overall objective of OSSPEEC is to develop an OLC pre-engineering degree program with curriculum articulation agreements with four year engineering programs at collaborating schools so that OLC students can successfully transition to a mainline school offering a BS degree in engineering. The intent of this paper is neither to analyze the overall success of the summer camps nor OSSPEEC in general. Neither is the intent to describe in detail the summer camp research projects nor the perspectives of project leaders from collaborating schools, OLC and SDSMT. This paper provides the perspective of project leaders from SDSU based on essays in which they reflect about capacity building through OSSPEEC summer camps for 2011-2013.

OSSPEEC is the South Dakota component of the overall NSF initiative, Pre-Engineering Education Collaborative (PEEC). A goal of all PEECs is to produce more Native American or Native Hawaiian engineers. The NSF PEEC initiatives began in 2010 and are continuing with funding of four PEEC projects including South Dakota, North Dakota, Hawaii, and Wisconsin. In each PEEC, at least one mainstream university collaborates with one or more TCC or Native Hawaiian served community college for a total of 12 awards to 17 institutions $^{5}$. 
Articles about the OSSPEEC summer camp experience from the perspective of partner collaborating schools include Sawyer et al. ${ }^{6}$ and Tinant et al. ${ }^{7}$, in this same proceedings. While those two articles and the current article only concern the summer camp aspect of OSSPEEC, other descriptions of OSSPEEC are available in the following articles: Fick et al. ${ }^{8-10}$. A search of the literature resulted in an extensive list of related topics that we present as tables later in this article (Appendix B, Tables 1-5). For Table 1, we selected other PEEC and particularly relevant non-PEEC articles. For Table 2, we located articles about indigenous and under-represented populations within STEM education. For Table 3 we chose articles about community-relevant education, retention, and bridging. For Table 4, we picked articles about the philosophy, intent, and implementation of experiential learning, particularly aspects of servicelearning (hybrid service-learning). For Table 5, we selected articles about ethics, social justice, and sustainable development.

The literature abounds with assessments of the general value of experiential learning, including service-learning for students in engineering education ${ }^{11-14}$. In the opinions of the editors of a capacity building project report for NSF, undergraduate research intervention activities for minority populations were developed, based on success with NSF-funded minority graduate students in STEM majors ${ }^{15}$. OSSPEEC summer camps incorporate experiential learning (including hybrid service-learning) and field based research (Figs. 2 and 3) for both undergraduate and graduate students to help build capacity for future success.

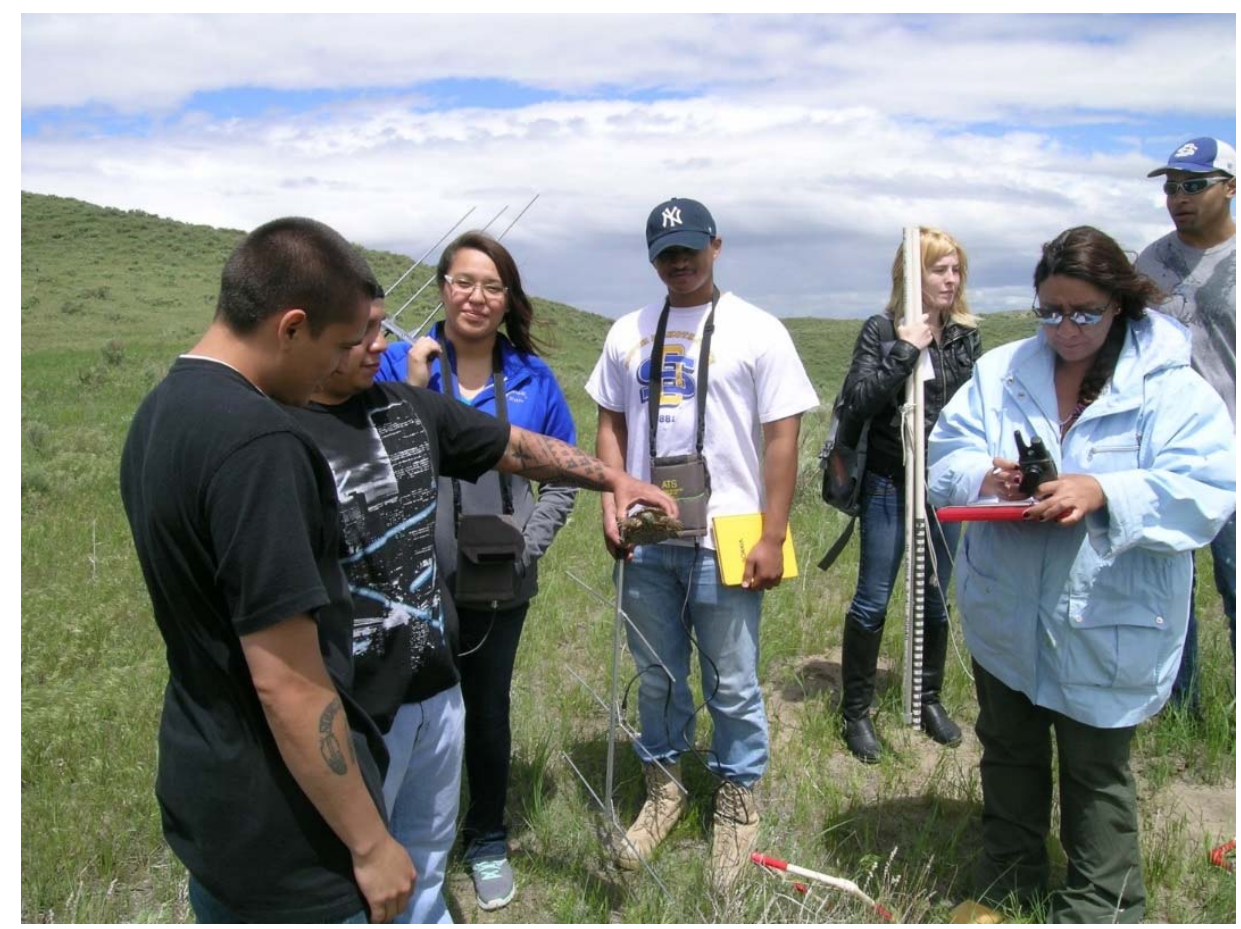

Figure 2. OSSPEEC student interns and staff collaborate on environmental research related to ornate box turtles, Terrapene ornata on PRR. Left to right: Willis Zephier, Osceola Blue Horse, Erin Yellow Hair, Peter Delgado, Cami Griffith, Ree West (OLC staff project coordinator, supervised by OLC project leader Ale Higa), and Sean Franklin, 2013 OSSPEEC summer camp. 


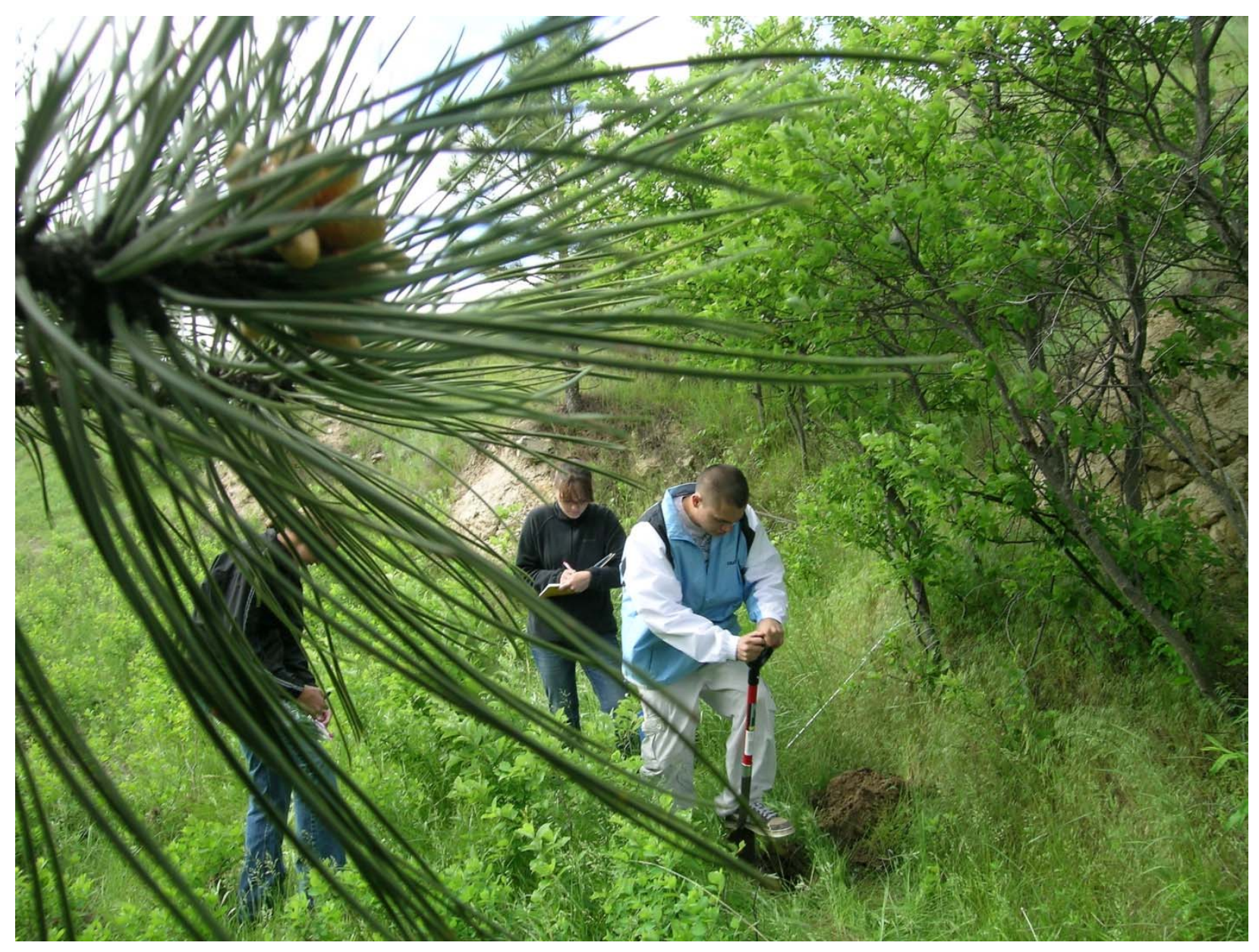

Figure 3. SDSU and OLC undergraduate student interns collect soil and plant tissue samples, under field supervision by an SDSU graduate student, to test for concentrations of heavy metals environmental contaminants at a site west of Wounded Knee on PRR, 2011. L to R: Laura Henery, Sadia Malik, and Willis Zephier. (Photos by J.M. Kant)

\section{Methodology}

The authors are both the researchers and the subjects of the research after the manner of Lord, et al. ${ }^{16}$, using constructivist, participatory action methodology ${ }^{17-18}$. The results are qualitative and narrative, extracted from four individual essays in response to pre-determined questions as the research instrument (Fig. 4). As researchers, we examined our resulting essays, and we present recurring themes as well as non-consensus opinions. We conducted a literature review and present selected references for all interested stakeholders related to OSSPEEC and similar initiatives, in which mainline universities collaborate with smaller colleges and universities that primarily serve underrepresented minorities. 


\section{CATEGORIES OF CAPACITY BUILDING CONCERNING OSSPEEC SUMMER CAMP FROM THE PERSPECTIVE OF SDSU}

1. Write a biography as the introductory part of your essay. It will be used to briefly describe why you are uniquely qualified to comment on the topic of capacity building through OSSPEEC summer camp experiences.

2. Write an essay explaining how we built capacity for each of the following through OSSPEEC summer camp experiences:
A. OLC as an institution
B. Pine Ridge Reservation
C. SDSU as an institution
D. SDSMT as an institution
E. Undergraduate students
F. Graduate students
G. Faculty and staff
H. Governmental agencies
I. Stem disciplines in general

Figure 4. Research instrument to produce essays.

\section{Our Qualifications to Comment on the Topic}

We authors are the researchers and the researched in this article. We are all women and nonNative Americans with advanced degrees. Kant, Burckhard, and Min are educators and researchers in the Jerome J. Lohr College of Engineering, Department of Civil and Environmental Engineering (CEE), at South Dakota's largest university, SDSU, with an estimated overall student population of 12,000. Kilts recently graduated with an MS in CEE at SDSU and is interviewing for a career in engineering in the private sector or with the Federal government. Our teaching experience at the university level ranges from over twenty years for Burckhard to a few years for Kant and Min, to none for Kilts.

We are uniquely qualified to comment on the topic of capacity building within OSSPEEC summer camps because we all participated in the project in a variety of roles. As a group, we represent a continuum of those participants with the most power to set policy and to create change, those in the middle, and those with the least. Appendix A lists brief biographical sketches detailing our qualifications to comment on the topic of interest in this article.

\section{Capacity Building: Recurring Themes}

Four recurring themes dominated the essays including the importance of: (1) using experiential learning pedagogy, (2) building lasting relationships and networking, (3) including crossdisciplinary connectivity, and (4) taking advantage of positive but unintended consequences. We divided opinions by themes, although some straddle more than one category or have implications 
for another category. We extracted the following comments from the four essays. We arranged them in the following order, identified by the italicized initials of the author: PI and Co-PI (S. R. Burckhard and K. Min), followed by the field supervisor (J. M. Kant), followed by the undergraduate student intern (W. K. Kilts). While we view OSSPEEC from four unique perspectives, we agree that capacity building is a major component of summer camps in the project, and it is a key measure of success because it builds potential for the future. We believe it is a necessary first step in building the numbers of students who complete the task of obtaining pre-engineering degrees and moving along to mainline universities.

\section{Using Experiential Learning Pedagogy}

Through summer camp hybrid service-learning projects, the PRR community identifies needs, and OSSPEEC students and faculty become involved in engineering issues that are important to local residents. It is a circular process that builds capacity for OLC with students and faculty conducting project based research across the vast expanse of the PRR. OSSPEEC summer camps produce higher visibility for OLC within PRR. Such awareness is important because it helps OLC to draw and to motivate students who can be involved in work that is meaningful in improving the quality of life on PRR.

- From the standpoint of undergraduate students from all three collaborating schools, OSSPEEC summer camps are important in building capacity. In many other college and university settings, undergraduate students typically lack the opportunity to work with faculty and graduate students in field based research and in hybrid service-learning projects that benefit the community. Such opportunities abound within OSSPEEC summer camps. The work is challenging and hands-on, and that motivates undergraduates. By working with faculty and graduate students, shoulder to shoulder, undergraduates see what they need to do to succeed, and they have close contacts, who mentor them. In some cases, undergraduates may not have the background to conduct the sophisticated research of which they are a part, but they are motivated to learn about the topic in order to solve problems that they see as relevant to quality of life on the PRR. That is not how learning occurs in most mainstream colleges and universities, but it works in OSSPEEC summer camps (SRB).

- For all three schools involved in OSSPEEC, experiential learning was beneficial for everyone involved. Hands-on learning seems to be preferred by students since they can see the benefit to be gained if they acquire skills that are of use in a real-world setting. For example, math becomes a subject that students learn not just for the sake of learning math. They learn because it has applicability for solving problems that help the community. The benefit to the PRR in collaborations using service-learning pedagogies is that community-identified needs may be met, and OLC and partnering schools became active partners in solving issues of local interest (KM).

- Capacity building for PRR is tied to helping OLC to be all that it can be. Selfdetermination on PRR can be increased through experiential learning pedagogies and through assembling evidence-based research to complement or to challenge the research of outsiders. That is crucial if PRR is to protect its self-interests and its environment, 
particularly if PRR elects to engage in extraction mining and other forms of potentially hazardous economic development (JMK).

- Experiential learning pedagogies help to motivate the many non-traditional students at OLC and the traditional and non-traditional students from participating mainline universities. The real-world experience is of great value in building student confidence to help them succeed. There is an immediate connection for students, since they are able to see how they need to attack a problem through innovative thinking and through building skill sets (JMK).

- For undergraduate student interns from other participating schools, they also gain unique experience in working with faculty and graduate students in field-based research on the vast PRR. In the best-case scenario, their projects include forms of service-learning, so that they interact with locals and listen to their needs and involve their participation. They gain understanding of the processes involved in obtaining permission to work on PRR, including a rough idea of the Institutional Review Board (IRB) and Research Review Board (RRB) protocols. Non-native students also gain an understanding of reservation culture, and many outsiders report reassessing their long-held beliefs about reservation life (JMK).

- A major capacity building for faculty is that they discover aspects of service-learning and other experiential learning pedagogies and how well they work (JMK).

- In visiting and working on PRR, persistent poverty is abundantly evident. The need for social justice drives many participating faculty to do something to empower those who live or work on PRR through educational opportunities, including some forms of servicelearning involving community voice. That creates capacity building because participating faculty encourage their peers to get involved, even if they are not a part of OSSPEEC (JMK).

- The summer camp experience provides OLC with a project to test different ways of applying experiential learning to determine what works and what does not work for their students. These lessons can then be applied to help Native students succeed. OLC is a leader among tribally controlled colleges in experiential learning (WKK).

- A number of the studies and projects conducted as part of OSSPEEC summer camp contribute to some of the goals of the Oyate Omniciye's Official Sustainable Development Plan of the Oglala Sioux Tribe ${ }^{20}$, especially the natural resource knowledge base goal, including plant, animal, and water studies (WKK).

- For students from a non-reservation background, such as I, the summer camp contributed to my cultural sensitivity (WKK).

- Such experiential learning helps to build research data about remote areas, and it shows potential in helping to raise student interest, making it easier to recruit and retain students in a cultural setting where STEM majors a under-represented. Some of the lessons 
learned could have the potential if applied in other settings involving under-represented minorities, poverty areas, or third world countries (WKK).

\section{Building Lasting Relationships and Networking}

Oglala Lakota College (OLC) built capacity through OSSPEEC summer camps by taking advantage of curriculum articulation agreements in their summer school program, forging alliances with mainline universities, networking with a variety of related projects, and enhancing their standing as a valuable resource through compiling research data from summer projects. By building lasting bonds within the OSSPEEC alliance, OLC is a stronger institution with more to offer their faculty and students.

- In building capacity, I cannot stress enough the primary importance of the continual building of trusting relationships between the PIs within OSSPEEC. That filters down to those whom they lead, but it starts with leaders (SRB).

- For SDSU, OSSPEEC summer camps build capacity because they create linkages to Native American college level students on our campus through their employment as summer interns. We share a connection to OLC with the state's other large engineering school, SDSMT. Summer camps on PRR also increase our networking with the American Indian Education and Cultural Center on the SDSU campus (SRB).

- OSSPEEC summer camps build capacity for participating faculty and staff because they provide a venue for them to increase diversity in recruitment of undergraduate and graduate students for STEM disciplines (SRB).

- In addition, summer camps provide unique research opportunities for faculty with results suitable for publishing, an important aspect of professional development (SRB).

- All faculty and staff benefit from networking with peers from other schools so they can grow as individuals. There is personal satisfaction in working with OSSPEEC summer camp participants, and we acknowledge the privilege of working on PRR. We value the trust that builds with each new contact with OLC and the OST (SRB).

- OLC is becoming a major player in PRR research, and its alliances with the State's two largest engineering schools increases the tribally controlled school's status and record of accomplishments. Conversely, SDSU's and SDSMT's association with OLC builds their capacity to meet their mission statements and long term goals (SRB).

- We held the 2014 summer camp kick-off meeting for OSSPEEC near Pine Ridge, SD, during the last week of May. Attendees included faculty and students from OLC, SDSU, and South Dakota School of Mine and Technology (SDSMT), as well as tribal government agencies. The meeting made me better understand tribal cultures and current issues in the environmental engineering field on PRR. In the future, I will work with OLC faculty and students on algae nutrient uptake (KM). 
- Both SDSU and SDSMT built capacity to understand issues facing OLC because of the relationships built with faculty, staff, and students from all three schools. In addition, SDSU and SDSMT faculty and staff better understand administrative and educational differences and similarities at their two schools. The more involvement there is between schools, the more networking is created. This has been shown in such simple ways as accumulating lists of e-mails to improve communications; the OSSPEEC Wiki site used to provide a central information source; and continuing communications between faculty, staff, and students on sites such as Linked-In. In short, those involved know people and their interests so that they have the contacts needed to make things happen both now and in the future. Those links were not nearly as strong when OSSPEEC began $(K M)$.

- SDSU has built capacity within its own campus. We forged relationships on our campus with others interested in experiential learning, including ABET accreditation using service-learning. We built relationships with the American Indian Education and Cultural Center (AIECC) faculty, staff, and students at SDSU. Our relationship with AIECC is particularly important because of their extensive knowledge and networking with Native American students on campus, as well as tribally controlled high schools, colleges, and universities in our region. They are a crucial link in our reaching those populations. If we are to build a pipeline to bring students to the SDSU Jerome J. Lohr College of Engineering, AIECC can play a key role. The AIECC also provides an invaluable sounding board for ideas to prepare more Native American students in STEM disciplines $(K M)$.

- As a part of capacity building, we are committed to building an effective pipeline of recruitment through stronger alliances with the reservation K-12 schools and all triballycontrolled colleges and universities in and near South Dakota (KM).

- We established relationships with administration, faculty, staff, and graduate and undergraduate students from OLC, SDSU, and SDSMT, as well as tribal, State, and Federal government agencies. During OSSPEEC summer camps, as an integral part of the project each year, we established field headquarters at a motel near Pica Wiconi, the administrative headquarters of Oglala Lakota College (OLC) near Kyle, SD, on Pine Ridge Reservation (PRR). The SDSU student interns and I lived there for about six weeks in May-June, during summers 2011 through 2013. During July, we returned to the Department of CEE at SDSU to use the microwave digester and the spectrometer in the Water and Environmental Engineering Research Center (WEERC) lab in Crothers Engineering Hall. At SDSU, we ran our field samples of plant tissue, soil, sediment, and water, testing for concentrations of heavy metals (JMK).

- OSSPEEC summer camps help build capacity for OLC because participation results in long-lasting relationships. While relationships between the OSSPEEC PIs and faculty are vital, equally important is mentoring of individual students by faculty and graduate students. Retention of faculty, staff, and students within OSSPEEC is valuable for longterm relationship building (JMK). 
- Some faculty and staff from all three campuses participated through their presence on PRR, and others worked with OSSPEEC participants through distance communication. Others worked during the second half of summer camp in activities related to laboratory work and poster production on campus at SDSU (JMK).

- Other ways that OLC gains capacity through OSSPEEC is by stockpiling and by making accessible the results of summer PRR research. That research provides a database of information upon which OLC can build. Data includes heavy metals results from several SDSU-initiated projects, as well as OLC- and SDSMT-initiated projects such as geological mapping, water quality, stream health, LIDAR, sustainable housing, among others. OSSPEEC helps OLC to build a reputation as a school with research capacity and the capability to work in tandem with South Dakota's two largest engineering universities. OSSPEEC reduces isolation for OLC and helps build communication that improves vitality and interconnectivity for all participating schools (JMK).

- For OSSPEEC-related heavy metals research projects, SDSU provided faculty and staff, including lab supervision by the senior chemist at SDSU's Water and Environmental Engineering Research Center (WEERC). The use of the WEERC lab included access to a microwave digester, spectrometer, vented hoods, refrigeration unit, ovens, lab ware, chemicals, argon gas, and disposable lab supplies. In addition, SDSU required and provided yearly, on-campus, lab safety training for all SDSU students and faculty working in labs. Such training provided capacity building for OLC because SDSU student-interns (including a student with dual enrollment at OLC and SDSU) and staff were certified to work in the WEERC lab and other labs that met safety requirements. Without such training, they could not participate in lab work (JMK).

- OSSPEEC also built capacity for SDSU and SDSMT because of the opportunities to conduct research projects alongside PRR residents and those who live elsewhere but work on PRR. Locals comprise a valuable resource because of their unique familiarity with the area $(J M K)$.

- Capacity building at SDSU includes stronger networking between CEE with the SDSU on-campus American Indian Education and Cultural Center's (AIECC's) faculty, staff, and students, including the Native American Club. An alliance between CEE and AIECC is building, with potential for recruiting, and retaining Native American engineering majors $(J M K)$.

- In examining the literature, searching for examples of increased capacity building from other NSF-sponsored Pre-Engineering Education Collaboratives (PEECs), the publications by participants at North Dakota State University (NDSU) were most helpful. For example, the NDSU model of working with all tribally controlled high schools and colleges in their state shows measurable success in bringing Native American students to engineering, and we strive to learn from their example (JKM). 
- I see capacity building happening through the lasting relationships built among faculty. There is a sense of camaraderie that they are blazing new trails and doing something that matters. There is great personal satisfaction in being part of OSSPEEC (JMK).

- The greatest benefit of OSSPEEC for tribal government and its various agencies on PRR is that OLC is increasingly seen as a "go-to" place for expertise from a tribally controlled college that is a trusted resource. Tribal government on PRR is making headway in producing and archiving information to defend their viewpoints about the management of reservation resources. Tribal government is now moving in the direction of increasingly relying on OLC and of integrating OLC students into tribal regulatory agencies, even before the students complete their degrees (JMK).

- OLC gained from having experienced engineering and science faculty work with them to help improve their pre-engineering program. The presence of faculty and students from SDSU and SDSMT helped to show what two ABET accredited universities would expect of students coming into their programs. Through the summer camps, OLC built connections with two mainline universities where OLC students may eventually transfer. The shared OSSPEEC summer camp experience may ease the transition to nonreservation schools (WKK).

- The summer camp sparked discussion, investigation, and networking with successful Native American students about factors underlying their successes (WKK).

- My time working in the WEERC lab provided an opportunity to know the lab's senior chemist and to demonstrate my lab skills to her. That helped me to obtain the WEERC lab assistant position in fall 2011. I worked there during my senior year and during graduate school. That employment helped me to finance and to finish my undergraduate degree and to attend graduate school (WKK).

- By interacting with 2013 summer camp interns in the SDSU lab, I met the summer interns' lab supervisor Dr. Karen Min, for whom I later worked as a teaching assistant $(W K K)$.

- For reservation-based students, OSSPEEC summer camp provides a unique introduction to SDSU or SDSMT campus life through interacting with off-reservation faculty and students. OLC students asked questions, got advice, and heard stories about the SDSU and SDSMT campuses and college communities and lifestyles from successful students attending those two colleges. That happened while they were in their comfort zone and the home turf of OLC and the reservation. ... Reservation-based students talked with Native students who had made the transition from the reservation or surrounding areas-to SDSU or SDSMT (WKK).

- The camp was a good opportunity for faculty and staff to network and to learn more about the talent available in the engineering and science departments at each institution. The relationships built might serve as a foundation for future collaborations involving reservation research undertaken by faculty and the students they mentor. Faculty from all 
three schools met students from other institutions, and they exchanged ideas about student preferences in learning styles. All of those events built capacity for faculty and staff (WKK).

- Two of the women student interns had completed the surveying course at SDSU. When the SDSMT professor gave us the surveying equipment, I wondered if he expected to teach us how to use it. We enjoyed his expression of happiness when we proved immediately competent because of our prior training. Shortly, he produced business cards and the talk of "you should consider SDSMT for graduate school" (WKK).

- Student interns from three different South Dakota colleges/universities have a chance to learn more about agencies such as Indian Health Services (HIS), South Dakota Department of Environment and Natural Resources (SDDENR), and United States Geological Survey (USGS). Student interns experience first-hand the types of projects in which these groups are involved. Governmental agencies can build stronger relationships with OLC, SDSU, and SDSMT. In particular, IHS is able to interact with students for purposes of recruitment for engineers and interns. Students who are interviewing for some of these positions have unique reservation experience to offer employers (WKK).

- The OSSPEC summer camp was also a key factor in a number of opportunities that helped me through graduate school. The camp provided an opportunity for me to know Drs. Berdanier and Burckhard, both OSSPEEC PIs. ... Summer camp helped me and other students to gain skills and confidence in interacting with faculty in general (WKK).

\section{Including Cross-Disciplinary Connectivity}

Another capacity building benefit resulting from OSSPEEC summer camps is SDSU's access to research opportunities on the remote and far-reaching PRR with its relatively unexplored natural resources. Another important factor is access to indigenous knowledge and working with local residents who are familiar with the locale.

- Graduate students heighten capacity building by playing the role of mentors and role models for undergraduates in OSSPEEC summer camps. The resulting research benefits all stakeholders, and it increases the level of sophistication of academics at OLC and builds their research databases that may spawn related projects (SRB).

- The multidisciplinary nature of the research is very appealing and beneficial for personal and professional growth. Diverse teams can solve complex problems in different manners compared to a team of all similar people (SRB).

- Capacity building increases because of OSSPEEC summer camps for Tribal, State, and Federal agencies. Summer camp participants produce evidence-based data that is valuable for governmental agencies in managing the region's varied natural resources. OSSPEEC summer projects result in data that is current and local, rather than outdated and regional $(S R B)$. 
- Project leaders from SDSU are especially concerned with heavy metals concentrations in water, sediment, plants, and soils on PRR, a topic with little evidence-based research history. We are beginning to better understand this locale with relatively high levels of naturally occurring heavy metals, particularly uranium, arsenic, and selenium (SRB).

- STEM disciplines should benefit from more inclusive and wider ranging points of view $(S R B)$.

- As one example, OLC experienced the regulations and training for lab safety that are required by SDSU faculty, staff, and students in order to be able to work in a campus lab containing hazardous materials, whether on their own campus or another. That resulted, unexpectedly, in lab safety training being offered at SDSMT for OSSPEEC faculty and students if they needed such training in summer 2013 (KM).

- We have seen in OSSPEEC cross-disciplinary fieldwork studies that we also encourage students in all fields of STEM, not just engineering. The experiential learning provides exposure to other fields, such as math, GIS, biology, and geology, so that students may discover interests about which they are passionate. Thereby, all STEM disciplines benefit from diversity enhancement, as we help build capacity by encouraging under-represented minorities to enter those disciplines $(K M)$.

- One of the most important capacity building aspects of SDSU's involvement in OSSPEEC is the benefit of cross-disciplinary research. Interdisciplinary field projects show students the value of science, technology, and math in solving engineering problems. By broadly defining "environmental engineering," in particular, students are better able to see the relationships. Cross disciplinary connectivity also helps students to identify their research passions and the necessity of mastering other skills of less interest that are necessary to reach their goals $(J M K)$.

- OSSPEEC increased capacity building for OLC by remaining flexible in approach. For example, OLC established a herbarium with professional quality plant vouchers as an offshoot of other OSSPEEC-related plant research on PRR that was initiated by SDSU in 2011 and 2012. Since OLC already had an unused herbarium case, establishment of their herbarium helped make use of existing equipment and helped them build an on-going resource for biological science and environmental engineering That advance is significant because PRR plants are largely unrecorded within mainstream science, and their existence is often simply inferred because most, but not all, grow in adjacent counties. The project also increased networking between OLC's and SDSU's herbaria, through participation and supervision of OSSPEEC students by curator Dr. Gary Larson of SDSU. In addition, SDSU provided laboratory space in Berg Hall and acid-free voucher paper and other materials and tools for the production of completed plant vouchers for the OLC herbarium in 2012 and 2013 (JMK).

- Another example of taking advantage of cross-disciplinary activities in the OSSPEEC alliance involves capacity building by assisting with plant identification at the rare turtle research project initiated by OLC on PRR. OSSPEEC faculty and students helped to 
enhance the research project through plant photography, collection, identification, and preparation for voucher assembly in 2013. While tracking and monitoring of rare turtles is a main focus for the project, adding to plant knowledge in defining the preferred habitation grounds complemented the research (JMK).

- I met many new people, and learned about their areas of interest. Student interns met others representing various STEM majors, and that helped us build multi-disciplinary teamwork and networking skills. For example, an engineer would evaluate and define a of type soil in a somewhat different manner than a plant scientist. We also learned some GIS skills, essential for our careers in that rapidly expanding field. Students gained experience in preparing and presenting field research either by Power Point or poster, before an audience of their peers and a variety of instructors (WKK).

- In my case, some of the benefits of the OSSPEEC summer camp experience became evident a year or so later. When talking to and comparing myself to some of my peers, I found that my transition to graduate school from undergraduate was noticeably easier. I was more prepared to participate in research projects and to manage my own thesis project. I was also more prepared to ask questions that helped lead to my thesis topic. The summer camp experience also provided me with valuable insight in how to plan and manage field work. The summer camp experience is a great way to introduce students to the research process by creating a mini-experience or an introductory experience that touches on the major steps: how to ask a research questions, methodology, sample techniques, data management, and data analysis (WKK).

\section{Taking Advantage of Positive but Unintended Consequences}

SDSU has many positive connections to Native American related projects throughout the state. We are working to make the most of each of those and to relate them to OSSPEEC summer camps where possible. We believe that we need to interest Native American students much earlier in their educations if they are to select engineering as a career choice. The OSSPEEC summer camp recruitment process brought that to our attention, and we are seeking remedies. That builds capacity for future success.

- Suddenly, engineering becomes relevant to daily life because it solves problems. Finally, local residents see what engineers do in a setting that is up close and personal. Now there are reasons why locals might want to consider engineering education because it is powerful. Besides the direct engineering projects, funds spent on the reservation boost the local economy $(S R B)$.

- Students may see and participate in a concept in the field then later learn about the theory behind the concept in a class. There are times when the undergraduate students know more than the graduate students or faculty, because we are on their home area. This is empowering for the undergraduate students to realize $(S R B)$.

- There is an aspect of social justice that is long overdue in the alliance that comprises OSSPEEC summer camps (SRB). 
- We invited engineers from Indian Health Service (IHS) to present career opportunities and to conduct an OSSPEEC field visit to a wastewater treatment plant in Kyle, SD in summer 2013. That provided another alliance within OSSPEEC, and it exposed students to professionals with careers in STEM. That was prompted by OSSPEEC student interns who expressed an interest in health careers related to their summer camp experience. Thus, we took advantage of unexpected opportunities as they arose (KM).

- At SDSU there is more interest in increasing the numbers of all under-represented minorities in engineering, including women. Thus, I see OSSPEEC having a ripple effect, particularly within STEM disciplines (JMK).

- I am an example of student capacity building. As an undergraduate, I was very sure that I did not want to go to graduate school or to write a thesis. My summer camp experience with OSSPEEC helped to change that. I graduated from SDSU in May 2014 with an MS in Civil Engineering (WKK).

- Prior to my OSSPEEC experience, I would not have considered IHS as a potential employer, but now as I finish graduate school, I am including them in my job search. My experience within OSSPEEC makes me more open to a career with the State, such as SDDENR (WKK).

\section{Non-Consensus Themes and Opinions}

While four consensus themes consistently dominated the four essays we wrote, non-consensus themes and opinions about capacity building also emerged. Those included social justice and unique opportunities for women engineers and scientists to succeed. Other secondary and nonconsensus themes included the importance of diversity within STEM disciplines and OLC's central position as a participant in current PRR research, including heavy metals concentrations in the overall environment, as well as water quality.

\section{Selected Bibliography}

After reviewing the literature, we selected the following references (Appendix B, Tables 1-5) that provide broader insights for effective implementation of "bringing engineering to Indians," as Paul Boyer ${ }^{5}$ refers to our overall goal. Table 1 includes North Dakota State University-related and other tribal collaborations in STEM, particularly engineering ${ }^{21-36}$. Table 2 includes indigenous and under-represented populations in STEM education ${ }^{10-11,16,37-45}$. Table 3 includes community-relevant education, retention, and bridging ${ }^{46-58}$. Table 4 includes philosophy, intent, and implementation of experiential learning, particularly service-learning ${ }^{12-14,59-79}$. Table 5 includes ethics, social justice, and sustainable development ${ }^{80-90}$. We recommend these references (and those by OSSPEEC authors previously cited in this article) for faculty, staff, graduate students, and undergraduate student interns within OSSPEEC, as well as others with an interest or engagement in similar initiatives. While each reservation and tribally controlled college is unique, through perusing these references, stakeholders may benefit from increased collaborative cohesion and from lessons learned from others. 


\section{Conclusion}

We introduced ourselves as four women engineers or scientists with advanced degrees, playing various roles in OSSPEEC, from PI's, to field supervisor, to undergraduate student intern. OSSPEEC is a multi-year NSF funded initiative between a TCC and two mainline universities with the main goal of bringing pre-engineering education to Native Americans. We extracted consensus opinions from the essays each of us wrote about the importance of capacity building through OSSPEEC summer camps for those involved and those outside the project. Four themes emerged, representing consensus opinions including: (1) experiential learning, (2) relationships and networking, (3) cross-disciplinary inclusion, and (4) flexibility and open-mindedness. We share our individually unique perspectives and experiences within the project, but we all agree that capacity building is a major component of OSSPEEC summer camps, and it may be viewed as a measure of success in the task of bringing engineering education to Native American students. We present selected references as a basis for understanding and enhancing collaborations between TCCs and mainline universities.

\section{Acknowledgments}

We gratefully acknowledge funding from the NSF under Grant \#1037708 that supports this research. We also thank the Oglala Sioux Tribe (OST) and OLC for hosting OSSPEEC and related research on PRR. We appreciate assistance of Professor Emeritus Janet Gritzner of SDSU in preparing the map for this article.

\section{Bibliography}

1. ACT, Inc. 2013a. The Condition of College and Career Readiness: American Indian Students. Author. Retrieved April 15, 2014 http://www.act.org/newsroom/data/2013/states/pdf/AmericanIndian.pdf.

2. ACT, Inc. 2013b. ACT Profile Report-National: Graduating Class 2013: American Indian/Alaska Native Students (pp.1-34). Author. Retrieved March 1, 2014 http://www.act.org/newsroom/data/2013/pdf/profile/AmericanIndian.pdf.

3. Annie E. Casey Foundation website 2014. Race for Results: Building a Path to Opportunity for All Children. Author: Baltimore, MD. Retrieved March 1, 2014

http://www.aecf.org/KnowledgeCenter/Publications.aspx?pubguid=\{5B863B11-62C7-41EC-9F7F6D12125C4DC2\}.

4. National Science Foundation (NSF) (2013). Women, Minorities, and Persons with Disabilities in Science and Engineering: 2013. National Center for Science and Engineering Statistics, Directorate for Social, Behavioral and Economic Science, 1-293. Retrieved June 19, 2014 http://nsf.gov/statistics/wmpd/2013/pdf/nsf13304_full.pdf.

5. Boyer, P. 2012. Bringing Engineering to Indians: A status report on the National Science Foundation's PreEngineering Education Collaborative. Washington, D. C.: NSF. Retrieved March 5, 2014

www.swc.tc/Scott\%20Morgan/Bringing_Engeering_to_Indians.pdf. 
6. Sawyer, J. F., Kant, J. M., Benning, J. L., Fick, D. R., \& Burckhard, S.R. Forging Partnerships, Experiential Learning, and Community Impact: Capacity Building Matters. The 2014 ASEE North Midwest Section Conference, Iowa City, Iowa, October 2014 (in review).

7. Tinant, C. J., Kant, J. M., LaGarry, H. E., Sanovia, J. J. \& Burckhard, S. R. Building Trust, Experiential Learning, and the Importance of Sovereignty: Capacity Building in Pre-Engineering Education - A Tribally Controlled College Perspective. The 2014 ASEE North Midwest Section Conference, Iowa City, Iowa, October 2014 (in review).

8. Fick, D.R., Sawyer, J.F., and Tinant, C.J. 2013. Retention and Recruitment as Part of a Pre-Engineering Education Collaborative. Proceedings of the ASEE Rocky Mountain Section Regional Conference, Pueblo, Colorado, March, 2013.

9. Fick, D.R., Gribb, M. M., and Tinant, C.J. 2013. The Impact of Project-Based Service Learning in a Native American Community on Student Performance in Civil Engineering Capstone Design. Proceedings of the $43^{\text {rd }}$ ASEE/IEEE Frontiers in Education Conference, Oklahoma City, Oklahoma, October 2013.

10. Fick, D.R., Sawyer, J. F., Tinant, C. J., \& Berdanier, B. W. Civil and Geological Engineering Service-Learning Projects As Part of a Pre-Engineering Education Collaborative. Proceedings of the $42^{\text {nd }}$ ASEE/IEEE Frontiers in Education Conference, Seattle, Washington, October 2012.

11. Barrington, L., \& Duffy, J. Attracting Underrepresented Groups to Engineering with Service-Learning. Proceedings of the ASEE International Exposition and Conference, Honolulu, Hawaii, June 2007.

12. Coyle, E. J., Jamieson, L. H., \& Oakes, W. C. 2005. EPICS: Engineering Projects in Community Service [Purdue]. International Journal of Engineering Education 21(1), 139-150.

13. Oakes, W. 2009. Creating Effective and Efficient Learning Experiences While Addressing the Needs of the Poor: An Overview of Service-Learning in Engineering Education. Proceedings of the ASEE Annual Conference and Exposition, Austin, Texas, June 2009.

14. Colledge, T. H. (Ed.). 2012. IJSLE, scholarship, and the academic community. International Journal for Service Learning in Engineering, 7 (2), 1-8 editorial. Retrieved March 1, 2014 http://library.queensu.ca/ojs/index.php/ijsle/article/view/4523/4553.

15. George, Y. S., Malcom, S. M., \& Campbell, P. (Eds.) 2011. Measuring Diversity: An Evaluation Guide for STEM Graduate Program Leaders. American Association for the Advancement of Science (AAAS). A Final Product of an Evaluation Capacity Building Project Funded by the National Science Foundation. Retrieved June 18, 2014 http://www.nsfagep.org/files/2011/04/MeasuringDiversity-EvalGuide.pdf.

16. Lord, S. M., Cashman, E. M., Eschenbach, E. A., \& Waller, A. A. Feminism and Engineering. Proceedings of the 35th ASEE/IEEE Frontiers in Education Conference, Indianapolis, Indiana, October 2005.

17. Denzin, N.K. 1997. Interpretive Ethnography: Ethnographic Practices for the $21^{\text {st }}$ Century. Thousand Oaks, CA: Sage Publications.

18. Kemmis, S. \& McTaggart, R. 2005. Participatory Action Research, in The Sage Handbook of Qualitative Research, $3^{\text {rd }}$ Edition, N. K. Denzin \& Y. S. Lincoln (Eds.), Thousand Oaks: California: Sage Publications, 559-603.

19. Kant, J. M., Larson, G. E., Burckhard, S. R., Berdanier, B. W., and Meyers, R.T.(in review, 2014). Contemporary Use of Wild Fruits by the Lakota in South Dakota. Great Plains Research. Lincoln, Nebraska: University of Nebraska, Center for Great Plains Studies. 
20. Oyate Omniciye Consortium and Steering Committee. The Official Sustainable Development Plan of the Oglala Sioux Tribe, May 21, 2012, 1-269. Retrieved June 22, 2014 http://www.oglalalakotaplan.org/wpcontent/uploads/2013/11/Oyate-Omniciye-Final-.pdf. 


\section{Appendix A, Research Subjects’ Qualifications to Comment}

Joanita M. Kant: The first participant, representing one of the researchers and the researched, J. M. Kant, currently serves as a research scientist, focusing on OSSPEEC related projects, in the Department of CEE at SDSU. From January 2011 through December 2013, Kant worked as the service-learning coordinator for SDSU within OSSPEEC. During that period, she was a PhD candidate at SDSU in Biological Sciences with a Plant Science specialization, and graduated in December 2013. As an OSSPEEC staffer, she helped recruit student interns from SDSU for OSSPEEC, and worked as a graduate teaching assistant and a graduate research assistant in CEE.

Kant and the SDSU student interns lived on PRR for about six weeks in May-June, during summers 2011 through 2013. During those years SDSU established field headquarters at a motel near Pica Wiconi, the administrative headquarters and one of the campuses for OLC near Kyle, South Dakota. Each of those years during July, they returned to CEE at SDSU to use the microwave digester and the spectrometer in the Water and Environmental Engineering Research Center (WEERC) lab in Crothers Engineering Hall. There they ran field samples of plant tissues, soil, sediment, and water, testing for concentrations of heavy metals environmental contaminants.

During summer 2012, Kant and former OSSPEEC PI, Bruce Berdanier, continued to establish professional relationships, network with administration, faculty, staff, and graduate and undergraduate students from OLC, SDSU, and SDSMT, as well as tribal, State, and Federal government agencies. In August 2012, they attended a symposium in Minneapolis, Minnesota, to exchange ideas at a gathering of a variety of PEEC participant leaders, along with NSF staff ${ }^{5}$. Kant gained a broader understanding of PEEC projects through listening to challenges and proposed solutions from non-South Dakota PEECs, who were trying to accomplish the same task of collaboratively bringing engineering to Native Americans or Native Hawaiians. NSF staff encouraged all the PEECs to tell their stories to provide a better understanding of the task for evaluators, funders, and those to whom funders answer.

Within a grant from the South Dakota Humanities Council (SDHC), a state program of the National Endowment for the Humanities (NEH), Kant served as a PI in 2012-2013. She conducted plant research on Rosebud Reservation (Fig. 1) in a partnership including Native American participation and perspectives, as an adjunct to her research on PRR. In late summer 2012, Kant took up residence at St. Francis, South Dakota, on Rosebud Reservation during the week of the Rosebud Fair, where she conducted interviews with 32 participants, resulting in a journal article with others, currently in review by Great Plains Research ${ }^{19}$. She is a long-time speakers’ bureau scholar on Native American and minority topics for the SDHC.

Kant served as a service-learning consultant at SDSU in 2010 as an AmeriCorps VISTA (Volunteers in Service to America). Her work involved a campus-wide effort with a diverse student population and a wide variety of departments, including CEE, during a time when service-learning became part of CEE Capstone Design.

Suzette R. Burckhard: The second participant, S. R. Burckhard, is an OSSPEEC PI. She is a professor in the Department of CEE at SDSU since 1997, with teaching experience of nearly 30 years. She is a former USDA Water Quality Fellow. Burckhard teaches undergraduate and graduate student courses in environmental engineering, water quality and quantity in surface and 
groundwater. She manages the BSCE and MSCE programs at SDSU, including new student orientation, recruitment, and retention.

Burckhard began mentoring OSSPEEC students at SDSU since the project launched in 2010. Since summer 2013, she served as senior PI for OSSPEEC. Since 2011, she advised OSSPEEC students in heavy metals research at SDSU labs by providing advice and direction for sampling and analysis protocol, and interpretation of results. In spring 2014, she attended community outreach meetings at Pine Ridge, South Dakota, to listen to community concerns and needs that might be addressed by experiential learning projects.

Burckhard is a long-time advocate for under-represented minorities in STEM disciplines, including acting as faculty advisor for Society of Women Engineers. She taught the multicultural engineering seminar at Kansas State University. Currently, she conducts K-12 engineering outreach, including URMs in poverty areas. She co-hosts No Child Left Behind workshops for high school teachers to help incorporate engineering into high school classes. Burckhard is passionate about making engineering more appealing to Native American students because diversity matters in solving increasingly complex problems facing engineers in the modern day.

Kyungyan Min: The third participant, K. Min, is also an OSSPEEC Co- PI. When she began working on the project in June 2013, Min was a part-time research associate in the Department of CEE at SDSU. She continues to teach undergraduate courses at SDSU since August 2013 with a specialty in environmental engineering.

During OSSPEEC summer camp 2013, Min visited OLC’s Piya Wiconi campus laboratories in the Department of Math, Science, and Technology, near Kyle, South Dakota. She provided some OLC faculty with lab safety materials and protocols used by mainline universities.

During summer camp 2013, Min oversaw a presentation and field trip organized by Indian Health Service (IHS) for OLC. The presentation provided the opportunity for OSSPEEC students and faculty to learn about the Sanitary Facilities Construction Program of IHS, as well as career opportunities. IHS staff from offices in Martin and Pierre, South Dakota, described past and current PRR projects, including housing, drinking water, and wastewater treatment.

As a part of OSSPEEC summer camp 2013, Min assisted four Native American undergraduate student interns in analyzing heavy metals in soil samples collected on PRR, using facilities and instrumentation in the WEERC laboratory at SDSU. Once they completed the lab work, she assisted student interns at SDSU in preparing their posters and presentations.

In outreach activities to another TCC, Min conducted an experiential learning engineering workshop on water treatment processes at Sinte Gleska University on Rosebud Reservation (Fig. 1) in fall 2013. While her interests are in bringing engineering to Native American students, she specializes in tailoring workshop presentations to needs expressed by those college leaders and by using hands-on learning strategies.

Min attended the OSSPEEC 2014 summer camp kick-off meeting in Pine Ridge, South Dakota. Attendees included faculty and students from OLC, SDSU, and SDSMT, as well as OST governmental agency representatives. Thereby, she gained a better understanding of tribal culture and current issues related to environmental engineering on PRR. As a result, she plans to 
work with OSSPEEC students, staff, and faculty in collaboration with the OST on water projects related to algae nutrient uptake.

Whitney K. Kilts: The fourth participant, W. K. Kilts, served as an undergraduate student intern, working mostly as a research assistant during OSSPEEC 2011 summer camp. At the time, Kilts pursued dual degrees in Chemistry and Civil Engineering from SDSU. That summer, she assisted and shadowed a Native American, Civil Engineering graduate student, Jesse DeCoteau, whose goal was to earn an MS at SDSU. DeCoteau and Kilts collected river and tributary surface water and sediment samples in the field, mostly off-reservation in northwestern Nebraska and southwestern South Dakota. Their work included a few samples on PRR, but they mostly collected samples in areas south and west of reservation borders. The OST and OLC are particularly interested in the results because DeCoteau and Kilts sampled watersheds that directly impact PRR. The objective was to determine heavy metals concentrations in the field samples to help build evidence based research to help OST manage their natural resources.

Kilts also spent several days collecting stream data and surveying with the OLC and SDSMT groups and assisting with soil and plant collection and identification for a heavy metals project supervised by Kant of SDSU. After the SDSU crew moved back to Brookings, South Dakota, to use the WEERC labs to analyze field samples in July and August, Kilts assisted with the microwave digestion of surface water, sediment, soil, and plant tissue. During summers 2012 and 2013, Kilts worked as a part-time lab assistant with WEERC and aided the lab's senior chemist in preparing to host OSSPEEC summer camp graduate and undergraduate student interns. 


\section{Appendix B, Selected References, Tables 1-5}

\section{Table 1. Selected references: North Dakota State University-related and Rowan University- related tribal collaborations in STEM, particularly engineering.}

21. Davis, C., Padmanabhan, G., Pieri, R., Lin, W., Patterson, F., \& Cobb, S. (2000). The Genesis of a MultiInstitutional Collaborative Educational Initiative Proposal. Proceedings of the ASEE Annual Conference, Albuquerque, New Mexico, June 2000.

22. Davis, C. S. G., \& Finelli, C. J. 2007. Diversity and Retention in Engineering. New Directions for Teaching and Learning (111), 63-71.

23. Hartman, K., Bennett, B., Colombe, L., Davis, C., Guinn, J., Halvorson, G., Kubisiak, S., LaVallie, A., Lohnes, J., Long Feather, C., Longie, E., Lin, W., Marxen, H., Padmanabhan, G., Pieri, R., Perkins, W., \& Pfahl, M. 2007. A North Dakota Tribal College Faculty Model: Guiding Undergraduate Student Research in Science, Technology, Engineering, and Math. North Dakota Tribal College Faculty, North Dakota [State]University Faculty, \& North Dakota Association of Tribal Colleges, n.p., 11-27. Retrieved June 27, 2014

http://www.ndepscor.nodak.edu/NATURE/Documents/NDTribalCollegeFacultyResearchModel_8-30-07_final.pdf.

24. LaVallie, A., Khan, E., \& Padmanabhan, G. Community-Relevant Research for TCC STEM Student Retention, Proceedings of the ASEE Annual Conference, Atlanta, Georgia, June 2013.

25. LaVallie, A., Khan, E., \& Padmanabham, G. Impact of a Research Experience Program on North Dakota Tribal College STEM Student Retention. Proceedings of the ASEE North Midwest Section Conference, Fargo, North Dakota, October 2013. Retrieved April 5, 2014 http://whavenlabs.com/ASEEConference/html/papers/ASEENMWSC2013-0004.pdf.

26. Lin W., Padmanabhan, G., Pieri, R., \& Patterson, F. Experiences with and Lessons Learned in a STEM Summer Camp for Tribal College Students. Proceedings of the ASEE Annual Conference and Exposition, Honolulu, Hawaii, June 2007.

27. Lin, W., Padmanabhan, G., Pryor, S., \& Wiesenborn, D. Introducing Native American Community College Students to Engineering through Hands-On Exploratory Projects. Proceedings of the ASEE Annual Conference and Exposition, Honolulu, Hawaii, June 2007.

28. Mehta, Y., Jansson, P. M., \& Dorland, D. Learning through the Design of a Fish Hatchery for a Community on the Cheyenne River Reservation - An EWB [Engineers-Without-Borders] Service-Learning Project. Proceedings of the ASEE Annual Conference and Exposition, Honolulu, Hawaii, June 2007. Retrieved April 10, 2014 http://www.icee.usm.edu/icee/conferences/asee2007/authors/M.html.

29. Mehta, Y. \& Sukumaran, B. 2007. Integrating Service Learning in Engineering Clinics. International Journal for Service Learning in Engineering, 2 (1), 32-43. Retrieved March 2, 2014 http://library.queensu.ca/ojs/index.php/ijsle/article/view/2090/2190.

30. Padmanabhan, G., Lin, W., Pieri, R., Patterson, F., \& Cobb, S. Strengthening Native Pathways to Science and Engineering Education. Proceedings of the ASEE Annual Conference, Montreal, Canada, June 2002.

31. Padmanabhan, G., Lin W., Pieri, R., Patterson, F., Cobb, S. \& Davis, C. A University--Tribal Colleges--High Schools Partnership to Increase Native American College Graduates in Mathematics, Science, and Engineering. Proceedings of the ASEE Annual Conference, Salt Lake City, Utah, June 2004.

32. Padmanabhan, G., Lin, W., Pieri, R., Patterson, F., \& Khan, E. A Weekend STEM Enrichment Program for Tribal High School Teachers and Students. Proceedings of the ASEE Annual Conference and Exposition, Chicago, Illinois, June 2006. 
33. Padmanabhan, G. and Davis, C. A. Undergraduate Research Experience: A Collaborative Model for Tribal Community College Students, GC 2008-133, 7th Global Colloquium on Engineering Education, Cape Town, South Africa, October 2008.

34. Padmanabhan, G. \& Davis, C. Collaborative Research-Mentoring for Tribal College Students. Proceedings of the ASEE Annual Conference, Vancouver, B. C., Canada, June 2011.

35. Padmanabhan, G., Pieri, R. V., \& Davis, C. A Unique University-Tribal College Collaboration to Strengthen Native American Pathways to STEM Education. Proceedings of the ASEE Annual Conference and Exposition, Vancouver, B. C., Canada, June 2011.

36. Padmanabhan, G., De Saram, D. D., Schanandore, T. C., Schanandore, J., \& Pieri, R. V. A Surveying Course as Summer Experience for a Tribal College Pre-Engineering Program. Proceedings of the ASEE Annual Conference \& Exposition, Atlanta, Georgia, June 2013.

\section{Table 2. Selected references: Indigenous and under-represented populations within STEM} education.

11. Barrington, L., \& Duffy, J. Attracting Underrepresented Groups to Engineering with Service-Learning. Proceedings of the ASEE International Exposition and Conference, Honolulu, Hawaii, June 2007.

37. Boyer, P. 2011. Ancient Wisdom, Modern Science: The Integration of Native Knowledge at Tribally Controlled Colleges and Universities. Published by Salish Kootenai College Press, Pablo, Montana and Distributed by University of Nebraska Press, Lincoln, Nebraska.

38. Brown, E. The ST@R Project: An Initiative to Increase the Retention Rates of $1^{\text {st }}$ and $2^{\text {nd }}$ Year Underrepresented Students Enrolled in Electrical Engineering. Proceedings of the ASEE Annual Conference and Exposition, Honolulu, Hawaii, June 2007.

39. Calderón, J. Z. (Ed.). Race, Poverty, and Social Justice: Multidisciplinary Perspectives through Service Learning. Stylus Publishing, LLC. Proceedings of the ASEE Annual Conference and Exposition, Honolulu, Hawaii, June 2007.

40. Chesler, M., \& Scalera, C. V. 2000. Race and Gender Issues Related to Service-Learning Research. Michigan Journal of Community Service Learning, spec. (1), 18-27. Retrieved March 5, 2014 http://hdl.handle.net/2027/spo.3239521.spec.103.

41. Coles, R. 1999. Race-Focused Service-Learning Courses: Issues and Recommendations. Michigan Journal of Community Service Learning, 6(1), 97-105.

42. Coyle, E. J., Jamieson, L. H., \& Oakes, W. C. 2006. 2005 Bernard M. Gordon Prize Lecture*: Integrating Engineering Education and Community Service: Themes for the Future of Engineering education. Journal of Engineering Education, 95(1), 7-11.

43. Eschenbach, E. A., Cashman, E. M., Waller, A. A., \& Lord, S. M. Incorporating Feminist Pedagogy into the Engineering Learning Experience. Proceedings of the $35^{\text {th }}$ ASEE/IEEE Frontiers in Education Conference, Indianapolis, Indiana, October 2005. 
10. Fick, D.R., Sawyer, J. F., Tinant, C. J., \& Berdanier, B. W. Civil and Geological Engineering Service-Learning Projects As Part of a Pre-Engineering Education Collaborative. Proceedings of the $42^{\text {nd }}$ ASEE/IEEE Frontiers in Education Conference, Seattle, Washington, October 2012.

44. Green, A. E. 2001. “But you aren’t White”: Racial Perceptions and Service-Learning. Michigan Journal of Community Service Learning, 8(1), 18-26.

45. Grommes, A., \& Riley, D. R. Learning from Native Cultures: Educational Opportunities in Sustainability, Cultural Sensitivity, and Global Awareness. Proceedings of the ASEE Annual Conference, Salt Lake City, Utah, June 2004.

16. Lord, S. M., Cashman, E. M., Eschenbach, E. A., \& Waller, A. A. Feminism and Engineering. Proceedings of the 35th ASEE/IEEE Frontiers in Education Conference, Indianapolis, Indiana, October 2005.

Table 3. Selected references: Community-relevant education, retention, and bridging.

46. Bringle, R. G., Hatcher, J. A., \& Muthiah, R. N. 2010. The Role of Service-Learning on the Retention of FirstYear Students to Second Year. Michigan Journal of Community Service Learning 16 (2), 38-49.

47. Fleming, J., \& Ledogar, R. J. (2008). Resilience, an evolving concept: A Review of Literature Relevant to Aboriginal Research. Pimatisiwin, 6(2), 7.

48. Guillory, R. M., \& Wolverton, M. 2008. It's about Family: Native American Student Persistence in Higher Education. The Journal of Higher Education, 79 (1), 58-87.

49. HeavyRunner, I. 2009. Miracle survivor (Pisatsikamotaan): An indigenous theory on educational persistence grounded in the stories of tribal college students (Doctoral dissertation, University of Minnesota).

50. HeavyRunner I., \& DeCelles, R. 2002. Family Education Model: Meeting the Student Retention Challenge. Journal of American Indian Education 41 (2), 29-37. Retrieved April 2, 2014 http://jaie.asu.edu/v41/index.html.

51. HeavyRunner, I., \& Marshall, K. 2003. Miracle Survivors: Promoting Resilience in Indian Students. Tribal College Journal of American Indian Higher Education, 14 (4), 14-18. Retrieved April 2, 2014 http://pace.dbs.umt.edu/WISPages/MiracleSurvivors.pdf.

52. Mitchell, T. \& Daniel, A. Start: A Formal Mentoring Program for Minority Engineering Freshmen. Proceedings of the ASEE Annual Conference and Exposition and Exposition, Honolulu, Hawaii, June 2007.

53. National Academy of Engineering (NAE) (2006). Engineering Studies at Tribal Colleges and Universities. Washington, D. C.: The National Academies. Retrieved June 30, 2014

http://courses.cs.washington.edu/courses/cse590f/07au/docs/TribalCollegesAndUniversities.pdf.

54. Piket-May, M., \& Avery, J. Service Learning First Year Design Retention Results. Proceedings of the $31^{\text {st }}$ ASEE/IEEE Frontiers in Education Conference, Reno, Nevada, October 2001.

55. Reyhner, J. 1992. American Indians out of School: A Review of School-Based Causes and Solutions. Journal of American Indian Education, 31(3), 37-56.

56. Reyhner, J., \& Dodd, J. Factors Affecting the Retention of American Indian and Alaska Native Students in Higher Education. First Annual Expanding Minority Opportunities National Conference, Arizona State University, Tempe, Arizona, January 1995. 
57. Tinto, V. 2006. Research and Practice of Student Retention: What Next? Journal of College Student Retention, 8 (1), 1-19.

58. Yeh, T. L. 2010. Service-Learning and Persistence of Low-Income, First-Generation College Students: An Exploratory Study. Michigan Journal of Community Service Learning, 16(2), 50-65.

\section{Table 4. Selected references: Philosophy, intent, and implementation of experiential learning, particularly service-learning.}

59. Abes, E. S., Jackson, G., \& Jones, S. R. (2002). Factors That Motivate and Deter Faculty Use of ServiceLearning. Michigan Journal of Community Service Learning, 9, 5-17.

60. Berdanier, B. W., Stephens, B., Krantz, E., Lambert, J., Respec, R. C., Johnson, S. K., \& Tinant, C. J. Reflections on a Decade of International Service Learning. Proceedings of the ASEE North Midwest Sectional Conference, Marquette University, Milwaukee, Wisconsin, October 2009.

61. Butin, D. W. 2006. The Limits of Service-Learning in Higher Education. The Review of Higher Education, 29 (4), 473-498.

62. Chan, C. K. Y. 2012. Assessment for Community Service Types of Experiential Learning in the Engineering Discipline. European Journal of Engineering Education, 37 (1), 29-38.

63. Chin, N. (2004). Teaching Critical Reflection through Narrative Storytelling. [Special Issue]. Michigan Journal of Community Service-learning, 10 (3), 57-63.

14. Colledge, T. H. (Ed.). 2012. IJSLE, scholarship, and the academic community. International Journal for Service Learning in Engineering, 7 (2), 1-8 editorial. Retrieved March 1, 2014 http://library.queensu.ca/ojs/index.php/ijsle/article/view/4523/4553.

12. Coyle, E. J., Jamieson, L. H., \& Oakes, W. C. 2005. EPICS: Engineering Projects in Community Service [Purdue]. International Journal of Engineering Education 21(1), 139-150.

64. Dewoolkar, M. M., George, L., Hayden, N. J., \& Neumann, M. 2009. Hands-On Undergraduate Geotechnical Engineering Modules in the Context of Effective Learning Pedagogies, ABET Outcomes, and Our Curricular Reform. Journal of Professional Issues in Engineering Education and Practice, 135 (4), 161-175.

65. Dewoolkar, M. M., George, L., Hayden, N. J., \& Rizzo, D. M. 2009. Vertical Integration of Service-Learning into Civil and Environmental Engineering Curricula. International Journal of Engineering Education 25 (6), 1257 1269. Retrieved April 2, 2014 http://hdl.handle.net/2051/10924.

66. Duffy, J., Barry, C., Barington, L., Kazmer, D., Moeller, W., \& West, C. Service-Learning Projects in 35 Core Undergraduate Engineering Courses. Proceedings of the ASEE Annual Conference and Exposition, Pittsburgh, Pennsylvania, June 2008.

67. Dukhan, N. \& Schumack, M. R. 2010. Reflection-Based Assessment of Service Learning in Undergraduate Engineering. International Journal for Service Learning in Engineering, 5 (2), 32-43. Retrieved from http://library.queensu.ca/ojs/index.php/ijsle/article/view/2393/3129.

68. Furco, A. 2003. Issues of Definition and Program Diversity in the Study of Service Learning. In S. H. Billig \& A. S. Waterman, (Eds.), Studying Service-Learning: Innovations in Educational Research Methodology, 13-29. Mahwah, NJ: Lawrence Erlbaum Associates. 
69. Kumar, S., \& Hsiao, J. K. 2007. Engineers Learn "Soft Skills the Hard Way": Planting a Seed of Leadership in Engineering Classes. Leadership and Management in Engineering, 7 (1), 18-23.

70. Liu, C. Partnering with and Assisting Community Partners in Service-Learning Projects to Tailor And Articulate Project Requirements. Proceedings of the $35^{\text {th }}$ ASEE/IEEE Frontiers in Education Conference, Indianapolis, Indiana, October 2005.

71. McKay, V. C. \& Estrella, J. 2008. First Generation Student Success: The Role of Faculty Interaction in Service-Learning Courses. Communication Education, 57, (3), 356-372.

72. Oakes, W. 2004. Service-Learning in Engineering: A Resource Guidebook. Providence, RI: Campus Compact.

13. Oakes, W. 2009. Creating Effective and Efficient Learning Experiences While Addressing the Needs of the Poor: An Overview of Service-Learning in Engineering Education. Proceedings of the ASEE Annual Conference and Exposition, Austin, Texas, June 2009.

73. O'Meara, K., \& Niehaus, E. 2009. Service-Learning Is... How Faculty Explain Their Practice. Michigan Journal of Community Service Learning, 16(1), 17-32.

74. Polin, D. K. \& Keene, A. S. 2010. Bringing an Ethnographic Sensibility to Service-Learning Assessment. Michigan Journal of Community Service Learning, 16(2), 22-37.

75. Prentice, M., \& Robinson, G. 2010. Improving Student Learning Outcomes with Service Learning. American Association of Community Colleges (NJ1).

76. Prince, M. 2004. Does Active Learning Work? A Review of the Research. Journal of Engineering Education, 93(3), 223-231.

77. Savage, R. N., Chen, K. C., \& Vanasupa, L. 2007. Integrating Project-Based Learning throughout the Undergraduate Engineering Curriculum. Journal of STEM Education: Innovations \& Research, 8.

78. Tsang, E. (Ed.). 2000. Projects That Matter: Concepts and Models for Service-Learning in Engineering (Vol. 5). Sterling, VA: Stylus Publishing, LLC.

79. Ward, K., \& Wolf-Wendel, L. 2000. Community-Centered Service Learning Moving from Doing for to Doing with. American Behavioral Scientist, 43(5), 767-780.

80. Baillie, C. 2010. Waste for Life website. Retrieved March 2, 2014 http://wasteforlife.org/.

\section{Table 5. Selected references: Ethics, social justice, and sustainable development.}

81. Colby, A., \& Sullivan, W. M. 2008. Ethics Teaching in Undergraduate Engineering Education. Journal of Engineering Education, 97(3), 327-338.

82. Curry, J. M., Heffner, G., \& Warners, D. 2002. Environmental Service-Learning: Social Transformation through Caring for a Particular Place. Michigan Journal of Community Service Learning, 9, 58-66.

83. Endreny, T. A. 2004. Storm Water Management for Society and Nature via Service Learning, Ecological Engineering and Ecohydrology. International Journal of Water Resources Development, 20 (3), 445-462. 
84. Jue, D. 2011. Improving the Long-Term Sustainability of Service-Learning Projects: Six Lessons Learned from Early MIT IDEAS Competition Winners. International Journal for Service Learning in Engineering, 6 (2), 19-29. Retrieved February 2, 2014 http://library.queensu.ca/ojs/index.php/ijsle/article/view/3554.

85. Mitchell, T. D. 2007. Critical Service-Learning as Social Justice Education: A Case Study of the Citizen Scholars Program. Equity and Excellence in Education, 40(2), 101-112.

86. Pearce, J. M. 2006. Service Learning in Engineering and Science for Sustainable Development. International Journal for Service Learning in Engineering, 1(1), 1-4. Retrieved February 3, 2014 http://library.queensu.ca/ojs/index.php/ijsle/issue/archive.

87. Pritchard, M. S. 2000. Service-Learning and Engineering Ethics. Science and Engineering Ethics, 6(3), 413422.

88. Sangster, J. L., Nelson, A., \& Bartelt-Hunt, S. L. 2012. The Occurrence of Lead in Soil and Vegetables at a Community Garden in Omaha, Nebraska. International Journal for Service Learning in Engineering, 7(1), 28-39. Retrieved March 10, 2014 http://library.queensu.ca/ojs/index.php/ijsle/issue/archive.

89. Scott, J. B. 2004. Rearticulating Civic Engagement through Cultural Studies and Service-Learning. Technical Communication Quarterly, 13(3), 289-306.

90. Vader, D., Erikson, C. A., \& Eby, J. W. 2000. Cross-Cultural Service-Learning for Responsible Engineering Graduates. In E. Tsang (Ed.), Projects That Matter: Concepts and Models for Service Learning in Engineering, 149-160. Sterling, VA: Stylus Publishing, LLC. 